\title{
Addressing health workforce shortages and maldistribution in Afghanistan
}

Najibullah Safi, ${ }^{1}$ Ahmad Naeem, ${ }^{2}$ Merette Khalil, ${ }^{3}$ Palwasha Anwari ${ }^{4}$ and Gulin Gedik ${ }^{3}$

${ }^{2}$ WHO Country Office, Kabul, Afghanistan. ${ }^{2}$ Ministry of Health, Kabul, Afghanistan. ${ }^{3}$ WHO Regional Office for the Eastern Mediterranean, Cairo, Egypt. ${ }^{4}$ Independent consultant, Kabul, Afghanistan. (Correspondence to: Merette Khalil: merette.ramses@gmail.com)

\begin{abstract}
Background: Afghanistan has the second lowest health workforce density and the highest level of rural residing population in the Eastern Mediterranean Region. Ongoing insecurity, cultural, socio-economic and regulatory barriers have also contributed to gender and geographic imbalances. Afghanistan has introduced a number of interventions to tackle its health worker shortage and maldistribution.
\end{abstract}

Aims: This review provides an overview of interventions introduced to address the critical shortage and maldistribution of health workers in rural and remote Afghanistan.

Methods: A review of literature (including published peer-reviewed, grey literature, and national and international technical reports and documents) was conducted.

Results: The attraction and retention of health workforce in rural and remote areas require using a bundle of interventions to overcome these complex multidimensional challenges. Afghanistan expanded training institutions in remote provinces and introduced new cadres of community-based health practitioners. Targeted recruitment and deployment to rural areas, financial incentives and family support were other cited approaches. These interventions have increased the availability of health workers in rural areas, resulting in improved service delivery and health outcomes. Despite these efforts, challenges still persist including: limited female health worker mobility, retention of volunteer community-based health workforce, competition from the private sector and challenges of expanding scopes of practice of new cadres.

Conclusions: Afghanistan made notable progress but must continue its efforts in addressing its critical health worker shortage and maldistribution through the production, deployment and retention of a "fit-for-purpose" gender-balanced, rural workforce with adequate skill mix. Limited literature inhibits evaluating progress and further studies are needed.

Keywords: human resources, health workforce, Afghanistan, public health, training

Citation: Safi N; Naeem A; Khalil M; Anwari P; Gedik G. Addressing health workforce shortages and maldistribution in Afghanistan. East Mediterr Health J. 2018;24(9):951-958. https://doi.org/10.26719/2018.24.9.951

Received: 15/04/18; accepted: 01/08/18

Copyright (C) World Health Organization (WHO) 2018. Some rights reserved. This work is available under the CC BY-NC-SA 3.0 IGO license (https:// creativecommons.org/licenses/by-nc-sa/3.o/igo).

\section{Introduction}

The World Health Report 2006 declared a global health workforce crisis; today, more than a quarter of the world's countries still suffer shortages and a global shortfall of 17 million health workers is projected by 2030 (1). Since human resources are arguably the most essential asset of any system or organization, strengthening the health workforce and addressing the critical shortage must be made a priority in moving towards Universal Health Coverage (UHC) $(2,3)$. Imbalanced distribution, especially in rural and remote areas, poses a barrier in access to quality health services. Half of the world's population lives in rural areas, but $75 \%$ of doctors and $62 \%$ of nurses serve urban populations, which suggest a need to increase production, deployment and retention of rural-practicing health workers of all cadres (1).

Afghanistan has an estimated population of 31.6 million, of which nearly $77 \%$ lives in rural settings (Central Statistic Organization 2018 population estimates) (4). Afghanistan has the second lowest health worker density in the Eastern Mediterranean Region (EMR), with a ratio of 4.6 medical doctors, nurses and midwives per 10000 people, considerably below the threshold for critical shortage of 23 health care professionals per $10000(2,4)$. This figure breaks down to 1.2 doctors, 2.1 nurses and 1.3 midwives per 10000 people (4). However, the ranges for these densities are wide when comparing provinces; for instance, the density of doctors is eight times greater in Kabul than it is in Kunar (with approximately 0.5 doctors per 10000 people in Kunar compared to 4 doctors per 10000 people in Kabul). Nooristan has eight times as many nurses and five times as many midwives compared to its neighbouring province Kunar (with estimated densities ranging 0.5-4.2 per 10000 people and 0.5$2.5 / 10000$ respectively) (4). Geographic imbalances are prominent as there are 16.7 health workers per 10000 in rural areas, compared with 36 per 10000 in urban areas; most qualified health workers are in urban areas serving only $23 \%$ of the population (5). Doctors, nurses and midwives make $26 \%$ of the health workforce, whereas community health workers make up almost $46 \%$ (Figure 1).

Afghanistan's critical health workforce shortage is a 
Figure 1 Percent of health workforce by cadre (2016) (4)

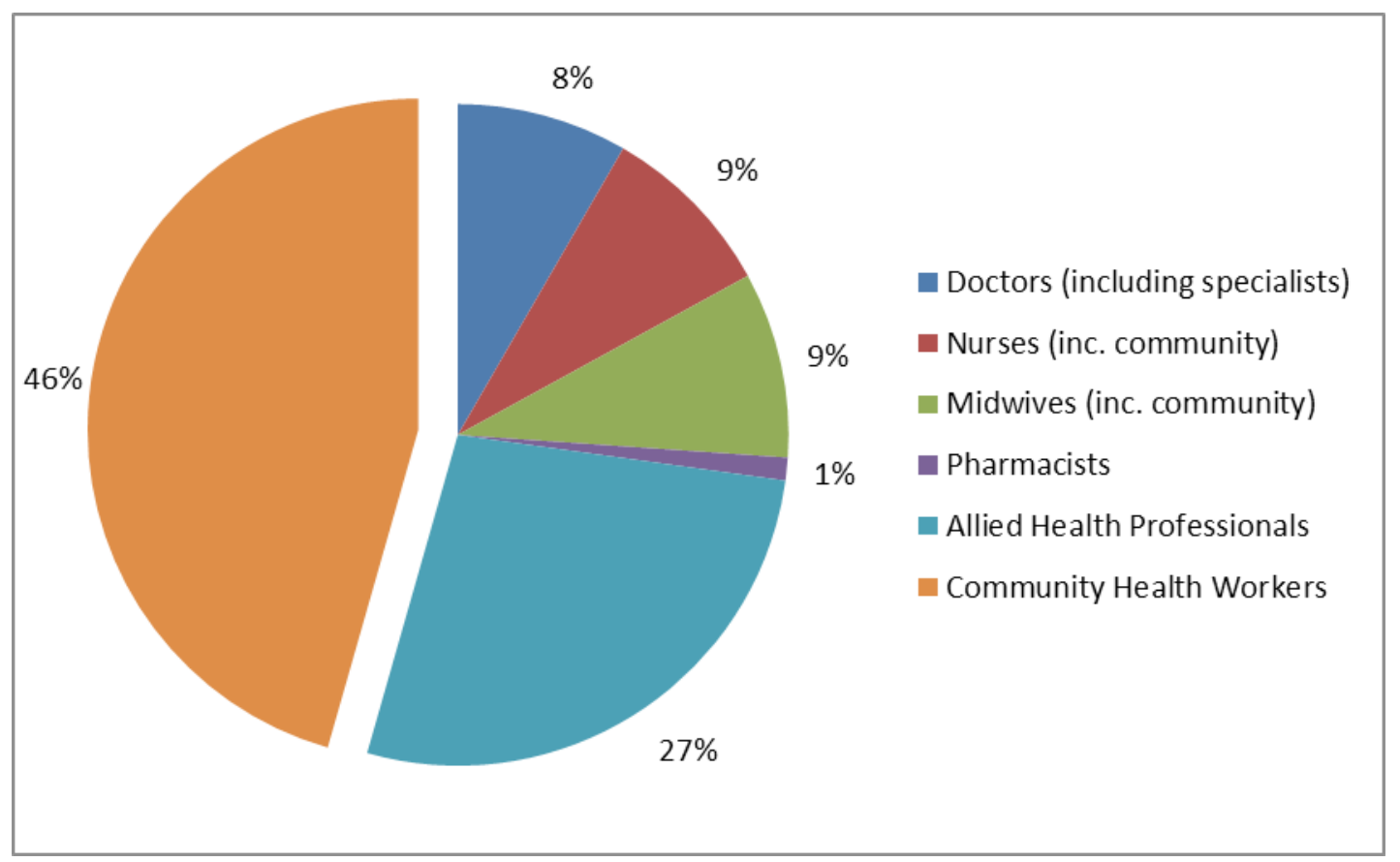

result of historic underinvestment in education and training, migration, lack of infrastructure and equipment and poor remuneration $(2,3)$. Other challenges also include lack of opportunities for career advancement, staff absenteeism, moonlighting, and weak management (2). Ongoing insecurity, harsh geographical terrain, cultural and socio-economic barriers have also contributed to the overall shortage as well as gender and geographic imbalances in the health workforce. As per the global pattern, many health workers (especially specialists and female doctors) prefer to work in Kabul and other regional centres for a notably better standard of life (i.e. security, employment, transportation, health care and education for their children) (5). In addition, the historic policies limiting girls' education (during the Taliban regime from 1995 to 2001) affecting health workforce production are still felt and encountered today, especially in more rural provinces. While Afghanistan has made significant advancements in the last two decades in increasing female education (World Bank shows female enrolment has increased from $6.6 \%$ in 2003 to $40 \%$ in 2017), enrolment does not translate into graduation, employment rates, or rural retention. The most recent DHS in 2015 showed 13\% of urban females completing some secondary schooling, compared to 5.6 fully completing secondary schooling and only 4.2 completing more; their rural counterparts were $5.2 \%, 1.5 \%$ and $0.6 \%$ respectively. Furthermore, in 2003 only a third of health facilities had a female health worker, and only about a quarter of the health workforce was female $(1,6)$. The conservative culture - more pronounced in rural areas - restricts women from receiving health services from male providers, amplifying the need for female health workers.
Afghanistan has been rebuilding its health system, with notable expansion of its Human Resources for Health (HRH). This review provides an overview of interventions used to tackle the critical shortage and distributional imbalances of health workers in rural and remote areas in Afghanistan.

\section{Methods}

A review of published and grey literature was conducted, searching PUBMED using key terms, such as: Afghanistan, health workforce, human resources for health, doctors, nurses, midwives, community health workers, retention, incentives, recruitment, deployment, rural, remote, underserved, fragile, fragile-state, post-conflict and low-income, mainly in literature after 2000. In addition to this, national plans, demographic health surveys, and technical documents produced by the Afghanistan Ministry of Public Health, and external development partners, were studied to understand the HRH situation. Unfortunately, there are inconsistencies in the available HRH data which prevents more comprehensive analysis across cadre, province and gender.

\section{Results}

Studies have shown that there is no model intervention that can be used to address critical shortages of health workers (7). Afghanistan uses a "bundle" approach, in accordance with the global recommendations to tackle its health workforce challenges (Table 1). Strategies related to recruitment, expanding production, focused deployment and retention have been used to address gender and geographic maldistribution.

\section{Expanding education and production}

From 2009 to 2011, there had been a 70\% increase in medi- 


\begin{tabular}{|c|c|c|}
\hline $\begin{array}{l}\text { Category of } \\
\text { Intervention }\end{array}$ & $\begin{array}{l}\text { Examples from the Global } \\
\text { Recommendations (23) }\end{array}$ & Examples in Afghanistan \\
\hline Education & $\begin{array}{l}\text { - Students from Rural Background } \\
\text { - Health professional schools outside of major cities } \\
\text { - Clinical rotations in rural areas } \\
\text { - Curricula that reflects rural health issues } \\
\text { - Continuous professional development for rural } \\
\text { health workers }\end{array}$ & $\begin{array}{l}\text { - Recruiting students from rural backgrounds ( } 8-10,21) \\
\text { - Creating special community-based cadres, trained, recruited } \\
\text { and deployed rurally: CM/E(Community Midwife/ Education) } \\
\text { and CHN/E (Community Health Nurse/Education) }(8,9,16,17,19) \\
\text { - Expanding pre-service training programmes to institutes in } \\
\text { remote provinces }(5,7,15,33) \\
\text { - CHW/CHN/CM curricula are based on rural health issues } \\
(6,7,9,21) \\
\text { - Continuous professional development (refresher courses for } \\
\text { CHW) (14,15) } \\
\text { - Consideration of preferential admission to meet quotas and } \\
\text { rural rotations }\end{array}$ \\
\hline Regulation & $\begin{array}{l}\text { - Enhanced scope of practice } \\
\text { - Different types of health workers } \\
\text { - Compulsory service } \\
\text { - Subsidized education for return of service }\end{array}$ & $\begin{array}{l}\text { - Introducing new cadres }(5,11,16,17,21,23) \\
\text { - Enhancing scope of practice, especially for CHN, CM }(21,25)\end{array}$ \\
\hline Financial & - Appropriate financial incentives & - Hardship allowances (double for women in rural health) (33) \\
\hline $\begin{array}{l}\text { Professional/ } \\
\text { Personal }\end{array}$ & $\begin{array}{l}\text { - Better living conditions } \\
\text { - Safe and supporting working environment } \\
\text { - Outreach support } \\
\text { - Career development programmes } \\
\text { - Professional networks } \\
\text { - Public recognition }\end{array}$ & $\begin{array}{l}\text { - Providing job opportunities to male family members } \\
\text { - Public recognition measures } \\
\text { - Afghan Midwifery Association (CPD, network) }\end{array}$ \\
\hline
\end{tabular}

cal students in Kabul; however, less than $20 \%$ medical students graduated from rural regional centers and only $25 \%$ were female (5). Although the production of female doctors has increased due to gender-based enrollment quotas, their attraction and retention to rural areas continues to pose a challenge towards equitable distribution. In 2012 , only a quarter of nursing graduates from Institutes of Health Sciences (usually in more urbanized areas) were female; Afghanistan tackled this issue by expanding nursing education to regional and provincial institutes, and introduced community nursing education in an effort to produce more female nurses in rural areas (5).

Acknowledging the immediate need for scaling up the health workforce, HRH National Strategy 2012 targeted training an additional 7000 nurses, 6000 midwives, 800 physiotherapists, 600 psychosocial counsellors, and 20000 volunteer community health workers, all trained in their provinces and bonded for employment locally, with the aim of retaining graduates in rural regions (5). Committed to rural health workforce production, Afghanistan expanded these pre-service trainings to many rural provinces. One study from 2015 showed there were 708 students preparing to graduate in nursing, midwifery, dentistry, pharmacy, physiotherapy and technology from Kabul's Ghazanfar Institute of Health Sciences (GIHS), compared to 2046 at the Institutes of Health Sciences in rural provinces (4).

Additionally, Afghanistan increased the number of health professional education institutions from nine medical, one pharmacy and one dental in 2012 to 32 medical, four pharmacy and six dental in $2017(4,5)$. Its most notable expansion has been with regards to nursing and midwifery: In 2009, there were only 21 pre-service training programmes. Afghanistan introduced communitybased nursing and midwifery cadres and expanded nursing and midwifery education to 8 institutes in rural provinces, with an additional 76 community-based preservice training programmes across most provinces. These community-based trainings are contracted out to private and international NGOs (4-8). Furthermore, Afghanistan established a standardized competencybased curriculum, leading to almost no difference in skills between midwifery graduates from private, public and community-based programmes (9). Afghanistan also built a national accreditation programme for midwifery education. By mandating that all midwifery schools achieve accreditation, over $91 \%$ were in compliance with national standards (10). Afghanistan has extended this model in building its accredited Community Health Nurse Education program, and can apply it in training emerging health professionals in bio-medical engineering, medical technology and environmental health.

Despite these efforts, Afghanistan still suffers from a shortage of health workers, and a lowered density of doctors, nurses and midwives from 7.6 in 2010 to 4.6 in 2017, particularly in the rural areas $(4,5)$. Deployment of Community Health Workers (CHWs) has become a common strategy to expand primary health care at the community level in many low- and middle-income countries with high rural population densities (11). Examples of national programmes include Ethiopia's 
30000 Health Extension Workers, Brazil's 250000 Community Health Agents, the Islamic Republic of Iran's 91000 Behvarz, Pakistan's 100000 Lady Health Workers, and India's 700000 Accredited Social Health Activists (11-13). Afghanistan has been using CHWs for decades to address the shortage of skilled health professionals, especially in rural areas (14). Community health workers are the first point of contact for patients in rural and remote areas and are responsible for implementing the Basic Package of Health Services at health posts, serving as village primary care providers (15). Given their pivotal role in rural health care, Afghanistan has expanded its programme in the last decade, doubling its CHWs from 20000 in 2011 to 40000 in 2016 (of which $50 \%$ are female) $(5,14)$. Today, CHWs make up almost $50 \%$ of the health workforce in Afghanistan (Figure 1) (4,5).

\section{Introduction of new cadres}

While Afghanistan has introduced multiple new cadres of health professionals, this section outlines two cadres that have specifically addressed the lack of female health workers in rural areas. Afghanistan introduced the community midwife in response to the historically high maternal mortality rate resulting from lack of skilled birth attendants (6). Community midwives (CMs) are recruited from and deployed to rural areas and trained in specific community-based pre-service programmes $(16,17)$. There is little difference between midwives and community midwives in terms of their training and practice; the main difference is their geographic location $(9,10)$. The demand for community midwives in rural areas is high, as seen by the high employability rates of community nominated and educated midwives compared to their urban peers $(9,16)$. Furthermore, the production of midwives has increased rapidly, almost 10-fold, from 467 in 2002 to 2167 in 2008, to 3484 in 2012, and 4600 in $2016(18,19,20)$.

In an attempt to address the shortage of female health workers in rural and remote areas, the community health nurse (CHN) was introduced in 2011 (21). While this cadre is not exclusively female, it is an attempt to increase the number of female nurses administering preventative, curative and rehabilitative 'first-line' care (21). Since 2011, there have been a total of 54 cohorts in 30 of Afghanistan's 34 provinces, enrolling a total of 1647 students (21). Notably, two provinces with over $96 \%$ rural population are actively enrolling and producing three cohorts of CHNs simultaneously. Many health facilities have celebrated the impact of the 'female CHN' on increasing the utilization of maternal and child health services.

\section{Strategic rural recruitment and deployment}

The strongest motivator associated with rural recruitment and retention is rural origins (22). Working environment, respectability, financial incentives and opportunities for professional advancement represent the other personal, professional and social factors $(7,23)$. Due to this, efforts have been made to recruit rural and community-nominated candidates, across all cadres, in hopes of increasing their retention in rural areas (23).
Community health workers are community members, nominated by a village health council (VHC), and then trained for a four-month period on prevention of infectious diseases, health promotion, family planning, and treatment of simple illnesses. While most CHWs are illiterate, they receive pictographic training manuals and continuous professional development in the form of a three-day refresher-training every six months (24). With regard to community midwives, 9th grade rural female students are hand-picked by their communities to attend community midwifery schools; community leaders formalize the nomination through a signed letter of support $(8,17)$. Similarly, most $\mathrm{CHNs}$ are recruited from, trained and deployed back in provinces where over $80 \%$ of the population is rural-residing (21).

This strategy of recruiting students from rural backgrounds has yielded higher deployment and retention rates of community nursing and midwifery students, as they have the continued support of their families and the recognition from their communities when they return to serve. According to one study, $96 \%$ of community midwifery graduates were employed $(63 \%$ in rural areas) compared with $74 \%$ midwives chosen by the Institutes Health Sciences (43\% in rural) and $82 \%$ (of whom only $9 \%$ in rural) by the National University Entrance Examination (9). Almost $60 \%$ of $\mathrm{CHN}$ graduates are deployed to public sector health facilities, in provinces with over $85 \%$ rural populations (21). Notably, provinces such as Bayman, Kapisa, Laghman and Uruzgan have a deployment rate over $80 \%$, where over $95 \%$ of the population lives in rural areas (10).

\section{Financial incentives}

Afghanistan has developed a national salary policy to standardize salaries and benefits paid to health care workers employed through the Basic Package of Health Services (BPHS) programme, and to motivate staff to work in rural and under-served areas. The policy includes payments of hardship allowances for rural and isolated areas, up to $250 \%$ of their base salary for female health providers $(15,25)$. However, it is well recognized that financial incentives are not the only motivating factor in attracting or retaining health workers to rural and remote areas (26). One study on midwives in Afghanistan ranked higher salaries in rural areas as lowest motivating factor at $9 \%$, preceded by mandatory service at $33 \%$ and family and community support at almost $60 \%(7,9)$.

\section{Social factors}

One of the biggest issues related to the deployment of the health workforce in rural and remote Afghanistan is that of insecurity. One benefit of recruiting and deploying students from rural backgrounds is their existing acclimation to the culture, pace and lifestyle, for those already residing in these insecure areas $(7,17,22)$. According to one study related to midwife deployment in Afghanistan, lack of security was cited by $42 \%$ as the most important deterrent from opting to work in rural and remote areas, while the remaining $58 \%$ reported other concerns including 
lack of medical equipment, proper schools for children and difficult living conditions $(6-8,10,26)$. This increased insecurity in remote areas further affects the mobility of health professionals, especially females. To increase the retention of female health workers in rural and remote areas, Afghanistan has started to provide opportunities for male family members and spouses to deploy to the same health facilities or villages through establishing linkages and collaboration with the Ministry of Labour and Social Affairs, providing recommendation letters for spouses to facilitate their job search, and improving the housing and schooling facilities around health facilities $(17,23,24)$. Additionally, public recognition remains a motivational factor in pursing rural posts; in the case of the community-nominated health workers, midwives and nurses, family and community support and pride facilitate their effectiveness and retention to their communities.

\section{Discussion}

Afghanistan has made noteworthy progress in its post-conflict development by increasing the densities of health workers, from 1 doctor, 1.29 nurse and 0.24 midwives per 10000 people in 2003, to 1.2 doctors, 2.1 nurses and 1.3 midwives in $2017(4,6)$. Despite these achievements, Afghanistan must continue developing its health workforce to surpass the threshold for critical shortage, and addressing gender and geographic imbalances in order to achieve the ambitious HRH 2030 agenda, UHC and the Sustainable Development Goals.

Since 2003, Afghanistan has doubled its female health workforce and further closing the gender-gap. In 2016, almost $50 \%$ of Afghanistan's health workforce is women (Figure 2) $(5,6)$. Since 2012, the percent of female allied health workers (dentists, laboratory technicians, radiologists and physiotherapists) increased from $9 \%$ to $46 \%$ in 2016 , while other cadres still lag behind with less than a quarter of their health workers being female $(4,5)$. These successes surely have strong implications on improving service delivery and increasing health outcomes. The number of health facilities providing BPHS has been increased from 1087 in 2004 to 1784 in 2011, and now 2604 in $2017(6,27,28)$. Number of health facilities with at least one female health worker has been increased from $45 \%$ (2000) to $74 \%$ in 2011 to $92 \%$ in $2017(4,6,27)$. Moreover, as a result of increasing the female health workforce and increasing the quality and availability of maternal health services, the maternal mortality ratio has improved significantly from 1100 (in 2000) to 396 per 100000 in $2015(19,20,28,29)$.

In addition to this, Afghanistan's efforts have increased the density of health workers in rural areas from 4.5 health workers per 10000 (in 2009) to almost 17 health workers per 10000 (in 2012) (5,30). While almost half of Afghanistan's provinces have over 95\% rural populations, provinces with the highest rural residing communities like Kunar, Ghazni, Faryab and Helmand still had the lowest densities of doctors, nurses and midwives; their utilization of CHWs at health posts was around the national average (only 0.6 active post/100o) (4). While Afghanistan's bundle of interventions has yielded improvements in closing the gender and geographic imbalances, there are still a number of cultural, financial and regulatory barriers inhibiting equitable distribution and accessibility to health workers.

Afghanistan's conservative culture affects recruitment and mobility of female health workers. Permission from the male head of family is necessary for a female to join the health workforce. A male CHW must accompany their female counterparts, fulfilling auxiliary tasks in transportation, management and environmental tasks $(14,15,24,31)$. This barrier is not unique to Afghanistan, as gender-based task allocation has been seen with female Behvarz in the Islamic Republic of Iran and Lady Health Workers in Pakistan (32). While historically there have been barriers to the recruitment and retention of female health workers due to traditional roles, family responsibilities and marriage, there has been an increase in the recruitment of female CHWs and community midwives as acceptability, community satisfaction, trust and improved health outcomes have been observed by their communities $(8,15,32)$.

CHWs make up about half of Afghanistan's total health workforce; these CHWs serve their communities on a voluntary basis (24). The biggest motivational push factor for volunteers is their desire to serve their community for religious and personal reasons. Recognition, and having the authority (and support from the community) to distribute contraceptives and simple medicines, provide counseling, and refer patients up to health facilities are attractive factors; however, delivering services without pay or remuneration offsets this pull. India, Ethiopia and Pakistan all utilize CHWs in delivering primary care; the only major difference is that their CHWs are salaried employees of the ministries and are often compensated in additional fringe benefits $(12,13,31,33)$. Data regarding retention of CHWs are sparse and inconsistent, showing dropout rates ranging from $10-80 \%$; the remuneration model (pay-for-service) and the "Family Health Worker" model (grandfathering school-aged children with the CHW curriculum) are proposed policies to address compensation and retention in Afghanistan $(15,24)$. The high expenses, reliance on international assistance and collaboration between stakeholders are also factors to be considered.

Competition with the private sector, due to the considerable salary inequalities and remuneration, is another factor that affects recruitment and retention. Despite financial incentives, such as pay and grading increases, health workers employed by projects/ programmes supported by international donors receive considerably more pay and allowances than their civil servant counterparts (e.g. doctors working for NGOs get $50 \%$ more salary than civil servants, and 'super-salaried' consultants often receive five times more) $(5,15,33)$. NGOs under contracted out arrangement for the implement of BPHS and EPHS are obliged to abide by the national salary policy, in addition to the recruitment guidelines, in order 
to reduce competition and inequalities. This overreliance on international donors is not unique to Afghanistan and is an issue faced by many post-conflict health systems in recovery, such as Sudan, Somalia, Democratic Republic of Congo, Cambodia and Zimbabwe (34).

While introducing new cadres increases the availability and accessibility of the health workers, multi-sectoral cooperation is required to address the implications of task-shifting and expanding scopes of practice on accreditation, formal recognition, curriculum development and certification. Separating registered nurses and CHNs as different cadres has been a challenge for regulatory bodies, as there are ambiguities in differentiating their scopes of practice (21).

Finally, there is little literature discussing the strategies used by low- and middle-income, developing, or post-conflict countries on addressing the shortage of health workers. Inconsistencies in data, from varied national and international sources have resulted in weaker evidence. There are even fewer studies documenting the effectiveness or impacts of these interventions on rural and remote recruitment and retention (26). Further studies and more specific data stratifying for cadres, gender and geographic location would be helpful in monitoring the direct impact of these interventions and evaluating the continued challenges in distribution and retention.

\section{Conclusion}

Despite the insecurity and geographic, economic and social barriers, Afghanistan is working to address its health workforce shortage, gender and geographic maldistribution through a bundle of interventions to achieve strategic recruitment, production, deployment and retention. Afghanistan has made progress in reducing gender imbalances and improved the availability of health workers in rural areas, resulting in improvements in access to health care and health indicators. However, the health system and health workforce challenges continue to have shortages with skill imbalances, rural deployment and concerns with the quality and performance of health workers. The need for further strengthening the health workforce remains pressing, including: expanding education capacities with emphasis on the quality of education; improving health systems management to retain motivated and well trained health workforce; and strengthening health workforce governance through improving engagement and coordination of leadership and all relevant stakeholders.

Funding: None.

Competing interests: None declared.

\section{Remédier à la pénurie et à la mauvaise répartition des personnels de santé en Afghanistan \\ Résumé}

Contexte : L'Afghanistan présente la seconde plus faible densité de personnels de santé et le niveau le plus élevé de population rurale dans la Région de la Méditerranée orientale. L'insécurité permanente, les barrières culturelles, socioéconomiques et réglementaires ont également contribué aux déséquilibres entre les sexes et les régions géographiques. L'Afghanistan a mis en place un certain nombre d'interventions pour remédier au problème de pénurie et de mauvaise répartition des personnels de santé.

Objectifs : La présente analyse donne un aperçu des interventions mises en place pour remédier à l'importante pénurie et à la mauvaise répartition critique des personnels de santé dans les zones rurales et isolées de l'Afghanistan.

Méthodes: On a procédé à une analyse de la littérature (y compris les publications de revues à comité de lecture, la littérature grise et les rapports et documents techniques nationaux et internationaux).

Résultats : Si l'on veut attirer et fidéliser les personnels de santé dans les zones rurales et isolées, il est nécessaire de mettre en place toute une série d'interventions pour relever ces défis pluridimensionnels et complexes. L’Afghanistan a créé des établissements de formation dans les provinces isolées, ainsi que de nouvelles catégories de praticiens communautaires. Le recrutement et le déploiement ciblés sur les zones rurales, les incitations financières et le soutien familial sont d'autres approches citées. Ces actions ont amélioré la disponibilité des personnels de santé dans les zones rurales, ce qui a permis de renforcer la prestation de services et les résultats sanitaires. Malgré ces efforts, des défis persistent, notamment la mobilité limitée des personnels de santé féminins, la fidélisation des personnels de santé communautaire bénévoles, la concurrence du secteur privé et les difficultés posées par l'élargissement des champs d'exercice des nouvelles catégories de praticiens.

Conclusions : Des progrès notables ont été accomplis en Afghanistan, mais le pays doit poursuivre ses efforts pour remédier à la pénurie critique en matière de personnels de santé et à leur mauvaise répartition grâce à la production, au déploiement et à la fidélisation d'une main-d'œuvre rurale « adaptée », avec un juste équilibre entre les sexes et faisant montre d'un éventail de compétences adéquates. Cependant, la littérature est peu fournie, ce qui ne permet pas d'évaluer les progrès et d'autres études sont nécessaires. 


\section{التصدي لنقص القوى العاملة الصحية، وسوء توزيعها في أفغانستان نجيب الله صافي، أحمد نعيم، ميريت خليل، بلوشة أنوري، فتحية جديك الك الك}

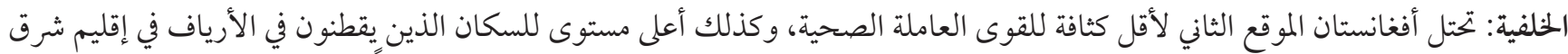

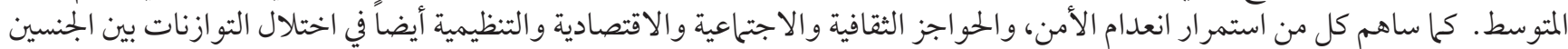

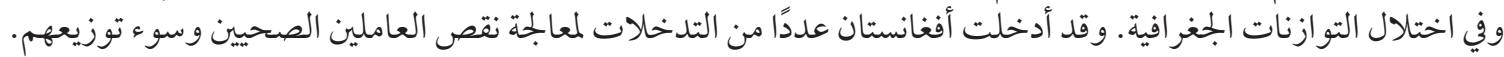

الأهداف: تقدم هذه المراجعة لمحة عامة عن التدخلات التي تم إدخالها لمعالجة النقص الجسيم وسو ألتاء التوزيع في العاملين الصحيين في المناطق الريفية والنائية في أفغانستان.

طرق البحث: أجريَت مراجعة للمنشورات (و التي تتضمن المطبوعات المنشورة بمراجعة الزملاء الأقران، والمنشورات الرمادية، والتقارير التقنية

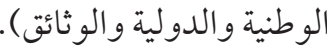

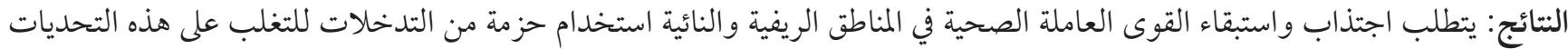

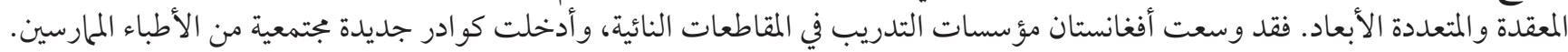

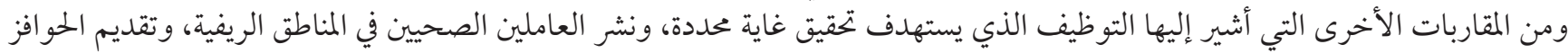

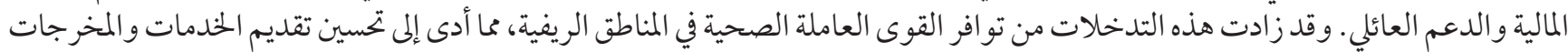

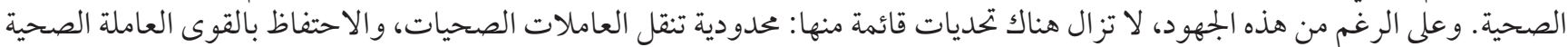

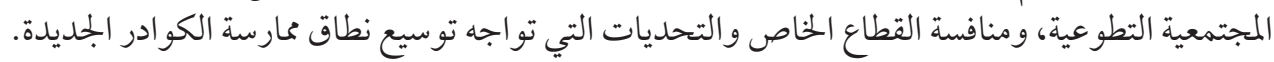

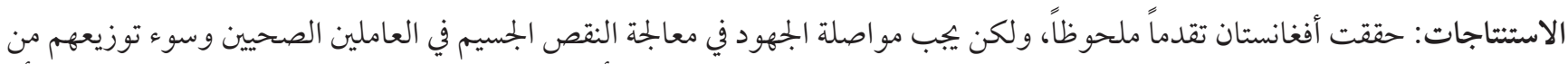

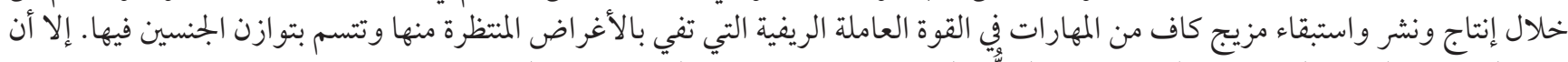

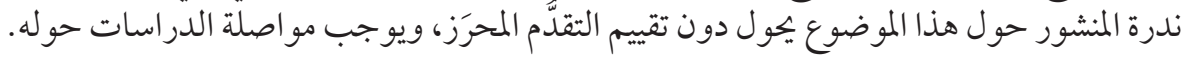

\section{References}

1. Lehmann U, Dieleman M, Martineau T. Staffing remote rural areas in middle- and low-income countries: a literature review of attraction and retention. BMC Health Serv Res. 200801 23;8(1):19. https://doi.org/10.1186/1472-6963-8-19 PMID:18215313

2. World health Organization. Global strategy on human resources for health: Workforce 2030. World Health Organization. World Health Organization; 2017 (http://www.who.int/hrh/resources/pub_globstrathrh-2030/en/).

3. El-Jardali F, Jamal D, Abdallah A, Kassak K. Human resources for health planning and management in the Eastern Mediterranean region: facts, gaps and forward thinking for research and policy. Hum Resour Health. 200703 23;5(1):9. https://doi. org/10.1186/1478-4491-5-9 PMID:17381837

4. Islamic Republic of Afghanistan Ministry of Public Health. National Health Strategy 2016-2020 [Internet]; Sep, 2016. Available from: http://moph.gov.af/Content/Media/Documents/MoPHStrategy2016-2020_FinalogSeptember2016111201614508950553325325.pdf

5. Islamic Republic of Afghanistan Ministry of Public Health; Evaluation and Health Information Systems (EHIS). General Directorate. Third Quarter Report 2017.

6. Islamic Republic of Afghanistan Ministry of Public Health; Afghanistan National Health Resources Assessment 2002 [Internet]. 2003 [cited 2017 Dec 16].

7. Determinants of Skilled Birth Attendant Utilization in Afghanistan. A Cross-Sectional Study | AJPH | Vol. 98 Issue 10 [Internet]. [cited 2017 Dec 16]. Available from: http://ajph.aphapublications.org/doi/10.2105/AJPH.2007.123471

8. Zainullah P, Ansari N, Yari K, Azimi M, Turkmani S, Azfar P, et al. Establishing midwifery in low-resource settings: guidance from a mixed-methods evaluation of the Afghanistan midwifery education program. Midwifery. 2014 Oct;30(10):1056-62. https://doi. org/10.1016/j.midw.2013.10.026 PMID:24290947

9. Mansoor GF, Hill PS, Barss P. Midwifery training in post-conflict Afghanistan: tensions between educational standards and rural community needs. Health Policy Plan. 2012 Jan;27(1):60-8. https://doi.org/10.1093/heapol/czroo5 PMID:21278372

10. Smith JM, Currie S, Azfar P, Rahmanzai AJ. Establishment of an accreditation system for midwifery education in Afghanistan: maintaining quality during national expansion. Public Health. 2008 Jun;122(6):558-67. https://doi.org/10.1016/j.puhe.2008.03.009 PMID:18460411

11. How effective are community health workers? An Overview of Current Evidence with Recommendations for Strengthening Community Health Worker Programs to Accelerate Progress in Achieving the Health-related Millennium Development Goals. Popline. Cape Town South Africa Human Sciences Research Council Publishers 2002;1970 [cited 2018Jan12] (https://www.popline. org/node/574691). 
12. Saprii L, Richards E, Kokho P, Theobald S. Community health workers in rural India: analysing the opportunities and challenges Accredited Social Health Activists (ASHAs) face in realising their multiple roles. Hum Resour Health. 2015 12 9;13(1):95. https://doi. org/10.1186/s12960-015-0094-3 PMID:26646109

13. Desta FA, Shifa GT, Dagoye DW, Carr C, Van Roosmalen J, Stekelenburg J, et al. Identifying gaps in the practices of rural health extension workers in Ethiopia: a task analysis study. BMC Health Serv Res. 2017 12 20;17(1):839. https://doi.org/10.1186/s12913-0172804-o PMID:29262806

14. Najafizada SAM, Labonté R, Bourgeault IL. Community health workers of Afghanistan: a qualitative study of a national program. Confl Health. 201412 1;8(1):26. https://doi.org/10.1186/1752-1505-8-26 PMID:25904976

15. Save the Children. Investing in health workers to save children's lives [Internet]. 2013 (http://healthworkers.savethechildren.net/ wp-content/uploads/2013/11/AFG_Health_Worker_Briefing.pdf).

16. Turkmani S, Currie S, Mungia J, Assefi N, Rahmanzai AJ, Azfar P, et al. 'Midwives are the backbone of our health system': Lessons from Afghanistan to guide expansion of midwifery in challenging settings. Midwifery. 2013Aug3; 29(10):1166-72.

17. Faqir M, Zainullah P, Tappis H, Mungia J, Currie S, Kim YM. Availability and distribution of human resources for provision of comprehensive emergency obstetric and newborn care in Afghanistan: a cross-sectional study. Confl Health [Internet]. 2015 Mar 16 [cited 2017 Dec 14];9. Available from: https://www.ncbi.nlm.nih.gov/pmc/articles/PMC4378548/

18. Islamic Republic of Afghanistan Ministry of Public Health. Afghanistan National Health Workforce Plan 2012-16 [Internet]. 2011 (http://www.who.int/workforcealliance/countries/Afghanistan_HRHplan_2012_draft_wlogos.pdf).

19. UNFPA Afghanistan | Afghan Midwives Association celebrates 11th Annual Congress in Herat (http://afghanistan.unfpa.org/ news/afghan-midwives-association-celebrates-11th-annual-congress-herat).

20. UNICEF. State of World Children-Afghanistan (https://www.unicef.org/sowcog/docs/SOWCo9-Panel-3.4-EN.pdf).

21. USAID. HEMAYAT: Helping Mothers and Children Thrive. Community Health Nursing Situational Analysis. 2016 Aug

22. Mbemba GIC, Gagnon M-P, Hamelin-Brabant L. Factors Influencing Recruitment and Retention of Healthcare Workers in Rural and Remote Areas in Developed and Developing Countries: An Overview. J Public Health Africa 2016 Dec 31 7(2) (https://www. ncbi.nlm.nih.gov/pmc/articles/PMC5345405/).

23. World Health Organization. Increasing access to health workers in remote and rural areas through improved retention (http:// www.who.int/hrh/retention/guidelines/en/).

24. Natiq K. Enhancing the CHW Model for Afghanistan. Afghanistan Journal of Public Health. 2017 Aug 19;1(1):7-11.

25. Edward A, Kumar B, Niayesh H, Naeem A, Burnham G, Peters DH. Association of Health Workforce Capacity and Quality of Pediatric Care in Afghanistan (https://www.hrhresourcecenter.org/node/5084).

26. World Health Organization. Evaluated strategies to increase attraction and retention of health workers in remote and rural areas (http://www.who.int/bulletin/volumes/88/5/09-070607/en/).

27. KIT The Royal Tropical Institute. The Balanced Scorecard Report: Basic Package of Health Services 2016. 2016 Aug.

28. Newbrander W, Ickx P, Feroz F, Stanekzai H. Afghanistan's basic package of health services: its development and effects on rebuilding the health system. Glob Public Health. 2014;9(sup1) Suppl 1:S6-28. https://doi.org/10.1080/17441692.2014.916735 PMID:24865404

29. WHO. Maternal mortality in 1990-2015 (http://www.who.int/gho/maternal_health/countries/afg.pdf).

30. Islamic Republic of Afghanistan Ministry of Public Health; Health Workforce Observatory Human Resources for Health Afghanistan Profile. 2009 Nov.

31. Lopes C. Sofia, et al. Rapid Assessment of Community Health Worker Knowledge Compared with Knowledge of Doctors and Nurses (https://www.hrhresourcecenter.org/node/611).

32. Javanparast S, Baum F, Labonte R, Sanders D. Community health workers' perspectives on their contribution to rural health and well-being in Iran. Am J Public Health. 2011 Dec;101(12):2287-92. https://doi.org/10.2105/AJPH.2011.300355 PMID:22021303

33. Belay TA. Building on Early Gains in Afghanistans Health, Nutrition, and Population Sector: Challenges and Options. World Bank; 2010. https://doi.org/10.1596/978-0-8213-8335-3

34. Durham J, Pavignani E, Beesley M, Hill PS. Human resources for health in six healthcare arenas under stress: a qualitative study. Hum Resour Health. 201503 29;13(1):14. https://doi.org/10.1186/s12960-015-0005-7 PMID:25889864 